\author{
Лілія Овдійчук, \\ кандидат педагогічних наук, доцент, \\ докторант кафедри української і зарубіжної літератури та \\ методик викладання, Університет Григорія Сковороди у \\ Переяславі (м. Переяслав, Україна) \\ Lilia Ovdiichuk, \\ Ph.D. in Pedagogy, docent, \\ Associate Professor of Pedagogy Department \\ of Ukrainian and Foreign Literarure and Methods \\ Hryhorii Skovoroda University in Pereiaslav \\ (Pereiaslav, Ukraine) \\ lilia_regi@ukr.net \\ ORCID ID 0000-0000-0002-0268-5969
}

УДК 378.37.01:[811.161.2+821.161.2]

\title{
ІНТЕГРАЦІЙНИЙ АСПЕКТ ВИВЧЕННЯ ІСТОРІЇ УКРАЇНСЬКОÏ ЛІТЕРАТУРИ В ПРОЦЕСІ ПІДГОТОВКИ МАЙБУТНІХ УЧИТЕЛІВ УКРАЇНСЬКОЇ МОВИ ТА ЛІТЕРАТУРИ
}

\begin{abstract}
АнотацІя. У статті акцентовано на важливому аспекті літературознавчої підготовки студентів спеціальності українська мова та літератури - вивченні курсу «Історія української літератури". Мета дослідження - визначити теоретико-методичні засади інтеграційного вивчення історії української літератури та репрезентувати формування на цій основі інтеграційнолітературознавчої компетентності майбутніх учителів української мови та літератури. У процесі роботи було використано теоретичні та емпіричні методи наукового дослідження. Аналітико-синтетичний та порівняльний методи застосовувалися в процесі вивчення наукових джерел. Емпіричний метод було використано під час вивчення питання в реальних умовах навчання. У науковому дослідженні репрезентовано зміст та методичне забезпечення інтеграційного вивчення історії української літератури. Розкрито різні види інтеграції: зовнішньопредметну, внутрішньопредметну, міжмистецьку, які реалізуються на змістовому рівні. Висвітлено взаємозв'язок із суміжними гуманітарними науками. Внутрішньопредметну інтеграцію між розділами літературознавчої науки про художню літературу, біографістику, компаративістику та між літературознавчими дисциплінами проілюстровано на прикладі опрацювання біографії та творчості письменників. Можливості міжмистецької інтеграції розкрито в процесі сприймання і розуміння художньої літератури з іншими видами мистецтв. У статті окреслено інтеграцію на діяльнісному рівні, яка відбувається шляхом упровадження в традиційний навчальний процес інновацій: технології критичного мислення, інформаційно-комунікаційних технологій; поєднання різних форм навчання: аудиторної та позааудиторної; навчальної та науково-дослідницької діяльності. У дослідженні представлено засоби (мультимедійні презентації лекцій, аудіо та відеозаписи), методи (проблемний, евристичний, ілюстрування), які застосовуються під час інтеграційного вивчення курсу «сторія української літератури». Доведено, що в процесі такого навчання формується інтеграційно-літературознавча компетентність, що виявляється через мотиваційно-ціннісний, когнітивно-рефлексивний, креативно-діяльнісний складники.
\end{abstract}

КлючовІ слова: майбутні вчителі української мови і літератури, зовнішньопредметна інтеграція, внутрішньопредметна інтеграція, міжмистецька інтеграція, діяльнісна інтеграція, інтеграція навчальної та науководослідницької діяльності, інтеграційно-літературознавча компетентність.

\section{INTEGRATING ASPECT OF STUDYING THE HISTORY OF UKRAINIAN LITERATURE IN THE PROCESS OF THE FUTURE TEACHERS OF THE UKRAINIAN LANGUAGE AND LITERATURE TRAINING}

\footnotetext{
Abstract. The article emphasizes the important aspect of literary studies training of the students of speciality Ukrainian language and literature - the study of the course "History of Ukrainian Literature". The purpose of the investigation is to determine the theoretical and methodological principles of integrating study of the history of Ukrainian literature and to represent formation of integration and literary competence of future teachers of Ukrainian language and literature on this basis. The theoretical and empirical methods of scientific research were used in the process of investigation. The analyticalsynthetic and comparative methods were applied in the process of studying scientific sources. The empirical method was used during the process of this issue studying in real learning conditions. The content and methodological support of the integrating study of the history of Ukrainian literature was presented in the research. The dfferent types of integration are revealed: extra-subject, intra-subject, inter-artistic, which are realized at the semantic level. The interconnection with the adjacent humanities is highlighted. Intra-subject integration between the sections of literary science on fiction, biography, comparative studies and among literary disciplines is illustrated by the example of elaboration of the writers' biography
} 
and creativity. The possibilities of inter-artistic integration are revealed in the process of perception and understanding of fiction with other arts. The article outlines the integration at the activity level, which occurs through the introduction of innovations in to the traditional educational process of innovations: critical thinking technologies, information and communication technologies; combination of different forms of education: classroom and extracurricular; educational and research activities. The study presents the means (multimedia presentations of lectures, audio and video recordings), methods (problem, heuristic, illustration), which are applied during the integration study of the subject «History of Ukrainian Literature». It is proved that in the process of such learning the integration-literary competence is formed, which is shown through motivational-value, cognitive-reflexive, creative-activity components.

Keywords: future teachers of Ukrainian language and literature, extra-subject integration, intra-subject integration, inter-artistic integration, activity integration, integration of educational and research activities, integration-literary competence.

\section{ВСТУП}

Постановка проблеми. У фаховій підготовці майбутніх учителів української мови та літератури одним із ключових є компетентнісний підхід. В основних документах, зокрема у законах України «Про вищу освіту» (2014), «Про освіту» (2017), визнано важливим «всебічний розвиток людини як особистості та найвищої цінності суспільства, її талантів, інтелектуальних, творчих і фізичних здібностей, формування цінностей і необхідних для успішної самореалізації компетентностей». Виокремлення інтеграційно-літературознавчої компетентності та її формування в процесі літературної освіти на сьогодні є важливим складником для забезпечення повноцінної фахової підготовки бакалаврів спеціальності 014 Середня освіта (Українська мова і література). Основою літературної освіти студентів означеної спеціальності $€$ історико-літературні дисципліни, зокрема «Історія української літератури», яка вивчається протягом восьми семестрів.

У процесі фахової підготовки майбутнього вчителя української мови та літератури повинен превалювати принцип поєднання змісту, форм, методів навчання з процесом взаємодії суб'єктів викладання та учіння. На цих засадах ґрунтується й літературознавча освіта бакалаврів, яка забезпечується теоретико- й істориколітературними курсами. Ці предмети є нормативними і базовими в професійній складовій навчального плану підготовки бакалаврів спеціальності 014 Середня освіта (Українська мова і література) (Навчальний план, 2018). Основою літературної освіти студентів означеної спеціальності $€$ історико-літературні дисципліни, зокрема «Історія української літератури» та «Історія зарубіжної літератури», які вивчаються протягом 8 семестрів. Найбільш значні за обсягом навчального матеріалу є історико-літературні монографічні теми. Вивчення їх в сучасних умовах діджиталізації освіти потребує певної методичної корекції та новітнього підходу. Розв'язання цієї проблеми можливе, якщо застосувати інтеграційний принцип опанування означених тем.

Аналіз наукових досліджень і публікацій. У сучасній педагогічній науці інтеграція опрацьовується науковцями у різних аспектах (функції, рівні, форми, типи, види). Українські вчені С. Гончаренко, Ю. Жидецький, М. Іванчук, С. Клепко, Я. Кміт, І. Козловська, Д. Коломієць, О. Комар, Р. Мустафіна, В. Нічишина, О. Сергеєв, В. Сидоренко, Я. Собко, Ю. Стиркіна, М. Чепіков, Л. Шаповалова, В. Якиляшек, Т. Якимович аргументують важливість формування системи предметно-інтегративного навчання як взаємодоповнення процесів інтеграції та диференціації. Учені розглядають міждисциплінарний підхід як такий, що інтегрує не тільки зміст, а й методи, моделі, дані з різних дисциплін. «Під змістом інтегративного підходу в професійній підготовці майбутніх учителів у вищій школі слід розуміти єдність процесів інтеграції змісту, форм та методів навчання і процесу взаємодії суб'єктів викладання та учіння при домінуючому значенні процесу інтеграції змісту», - зазначає науковець В. Нічишина (Нічишина, 2014, с. 178-179).

Особливості застосування інтеграційних методик у фаховій підготовці студентів у закладах вищої освіти були предметом наукових розвідок Д. Власова, М. Дзюбенко, Л. Дольнікової, Л. Ємчик, Я. Кміта, А. Колота, З. Курлянд, П. Лернера.

Процес професійної підготовки майбутніх учителів української мови та літератури в різних аспектах досліджували Л. Базиль, М. Вовк, Н. Волошина, Н. Голуб, О. Горошкіна, А. Градовський, Г. Клочек, С. Жила, О. Ісаєва, О. Караман, С. Караман, О. Копусь, В. Коваль, О. Куцевол, Н. Побірченко, Н. Остапенко, Н. Романишина, О. Семеног, Т. Симоненко, А. Ситченко, І. Соколова, Б. Степанишин, Г. Токмань, Ф. Штейнбук та ін., однак проблеми застосування інтеграційного підходу тільки частково торкалися Л. Базиль, О. Куцевол, Н. Романишина, акцентуючи на інтеграції навчальних дисциплін на літературознавчій основі та на поєднанні інноваційних форм і методів 3 традиційними і достатньо апробованими у вищій школі. Проблему інтеграції засобів ІКТ у систему професійної освіти майбутніх учителів української мови і літератури досліджують О. Кучерук, С. Караман, О. Караман, Н. Віннікова.

МЕТА І ЗАВДАННЯ ДОСЛІДЖЕННЯ - Визначити теоретико-методичні засади інтеграційного вивчення історії української літератури та розкрити формування на цій основі інтеграційно-літературознавчої компетентності майбутніх учителів української мови та літератури.

\section{МЕТОДИ ДОСЛІДЖЕННЯ}

У процесі дослідження було використано наукові праці з проблем інтегрованого підходу у фаховій освіті. Застосовано аналітико-синтетичний та порівняльний методи під час опрацювання наукових джерел. Емпіричний метод було використано під час спостережень за навчальним процесом, а метод моделювання - під час формування авторської методики інтеграційного вивчення історико-літературних монографічних тем.

\section{РЕЗУЛЬТАТИ ДОСЛІДЖЕННЯ}


Вивчення курсу «Історія української літератури» на інтеграційній основі потребує створення відповідних педагогічних умов: забезпечення міждисциплінарної інтеграції (змістовий аспект), інтеграції технологій, форм, видів діяльності та навчально-педагогічної взаємодії викладача і студента.

Аналіз програм, підручників та посібників з «стторії української літератури» для студентів закладів вищої освіти, які здійснюють підготовку майбутніх учителів української мови та літератури, дає підстави стверджувати, що матеріал розподілено за курсами й семестрами відповідно до етапів літературного процесу. У межах кожного періоду $є$ оглядові теми, які репрезентують основні тенденції розвитку, напрями, стилі, характерні особливості літературної доби та монографічні теми, у межах яких відбувається вивчення біографії і творчості письменників - репрезентантів цієї епохи. 3 огляду на обсяг матеріалу важливо вміло організувати навчальний процес, оптимізувати його і забезпечити формування загальних і предметних компетентностей під час вивчення історико-літературних тем. У контексті цього дослідження виокремлено інтеграційно-літературознавчу компетентність, яка формується у процесі інтеграційного вивчення української літератури на основі міждисциплінарних зв'язків на рівні змісту:

1) інтеграція внутрішньопредметна між розділами літературознавчої науки про художню літературу, біографістику, компаративістику та між дисциплінами історія літератури, теорія літератури, літературна критика;

2) інтеграція відомостей із суміжних гуманітарних наук: філософії, історії та культури України, психології - у процесі аналізу художнього тексту, вивчення біографії та літературного періоду;

3) інтеграція сприймання і розуміння художньої літератури з іншими видами мистецтв;

4) інтеграція з методикою навчання літератури, зорієнтована на підготовку до викладання літератури в школі.

На діяльнісному рівні відбувається:

1) інтеграція інновацій (технології критичного мислення, IKT) у традиційний навчальний процес; 2) інтеграція форм навчання: аудиторних занять та самоосвіти (самостійної та індивідуальної роботи); 3) інтеграція аудиторної та позааудиторної діяльності; 4) інтеграція дистанційного з аудиторним навчанням; 5) інтеграція навчальної та науководослідницької діяльності.

На рис. 1. відтворено основні аспекти зовнішньопредметної та внутрішньопредметної інтеграції й види, способи інтеграції сприймання і розуміння художніх творів з іншими видами мистецтва.

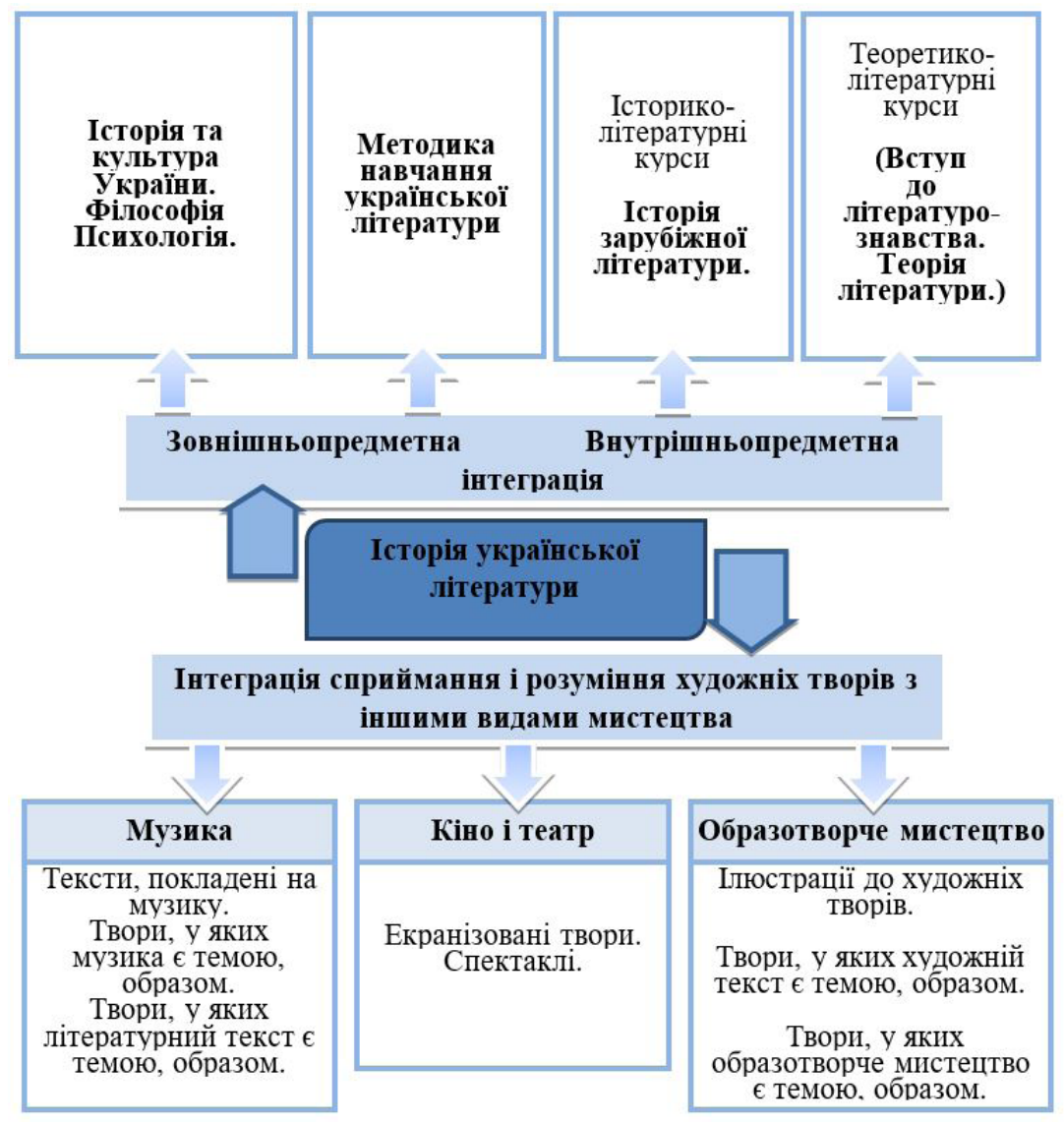

Рис. 1. Взаємозв'язки курсу «Історія української літератури» з іншими дисциплінами та видами мистецтва

Апробація методики викладання монографічних та оглядових історико-літературних тем на основі інтеграційного підходу уможливила авторці статті узагальнити напрацювання з цієї проблеми й винести їі для обговорення на сторінки науково-методичної преси. Важливим підґрунтям успішного вивчення монографічних тем $є$ створення відповідного навчального середовища, яке відображає інтеграційний аспект: добір матеріалу для занять, форму їх 
проведення (різновиди лекцій, практичних; аудиторні, позааудиторні), а також технології, форми, методи і прийоми, які застосовуються в поєднанні (традиційні, інноваційні).

Для прикладу: зовнішньопредметна інтеграція курсу «Історія української літератури» 3 дисципліною «Історія та культура України» є очевидною. Контекст історичної доби можна відтворити тільки на основі інтегрованих знань про «дух епохи», тобто про суспільно-політичні події, наукові досягнення, культурно-мистецькі здобутки та художню літературу. Найкращим чином це відобразить графічний систематизатор у вигляді універсальної синхронної таблиці-матриці з відповідними складниками. До цієї таблиці студенти звертаються в процесі вивчення оглядових та монографічних тем, оскільки вона дає підґрунтя і матеріал для розуміння загальної картини історико-літературного періоду, а також допомагає зрозуміти витоки творчості письменників.

Під час опрацювання іншого літературного періоду студенти отримують завдання заповнити окремі розділи самостійно, а коли будуть сформовані відповідні навички використання стратегій критичного мислення, підготувати графічний систематизатор без допомоги викладача. Таким чином знання з різних дисциплін концентруються навколо однієї теми, що дає можливість студентам застосовувати їх у конкретних ситуаціях, тобто оволодівати загальними й предметними компетентностями у взаємозв'язку.

Інтеграційне вивчення монографічних тем репрезентовано в авторській статті (Одійчук Л., 2020) на прикладі теми «Іван Франко: життя і творчість». В електронній медіатеці «Письменник як особистість», яка сформована авторкою дослідження на Google-диску, є мультимедійна презентація «Іван Франко як особистість» (Овдійчук Л., 2016). Основним змістовим матеріалом $€$ уривки 3 першоджерел (листів, спогадів про письменника, мемуарів самого митця, щоденникових записів) та фотопортрети письменника, дружини, друзів, а також документи, які засвідчують важливі життєві події, фото книг (виданих творів), ілюстрації до творів тощо. У традиційний навчальний процес інтегруються новітні технології, які уможливлюють візуалізувати і продемонструвати студентам оцифровані раритетні матеріали, спонукати до їх уважного прочитання, розуміння, аналізу, осмислення, критичної оцінки і з'ясувати, як сформувалася така особистість. Апробація відбувалася під час лекційних та практичних занять в аудиторії і дистанційно й дала позитивні результати. Про це свідчать контрольні зрізи у формі анкет, есе, які продемонстрували ефективність авторської методики і виявили підвищення рівня знань з базової дисципліни.

Один із видів інтеграції, зокрема сприймання і розуміння художніх творів з іншими видами мистецтва: музикою, живописом, театром, кіно, є важливим доповненням до аналітико-синтетичної роботи над змістом і формою твору. Окрім того, це ефективний засіб для формування ціннісних орієнтирів майбутнього вчителя української мови та літератури та для реалізації мотиваційно-аксіологічного компонента його фахової підготовки. Сучасні технології (наприклад, пошуковий сервіс Google) дають змогу легко знайти музичні, живописні твори, театральні вистави, кінофільми, які репрезентують українську літературу в інтерпретації сучасних композиторів, артистів, живописців, режисерів, акторів. До прикладу, для ознайомлення з пісенно-музичними інтерпретаціями поезій пропонуємо студентам знайти за покликанням топ-30 пісень на вірші українських поетів, послухати й проаналізувати тексти у взаємодії слова й мелодії, голосу та манери виконання. Для цього спонукаємо студентів залучати знання 3 музикознавства, зокрема, про сучасні стилі (рок, реп, фанк, фолк).

Запитання, які формулюємо, поєднують літературний текст і музику. Що додала мелодія віршу? Який характер мелодії? Який ритм обрано? Чому? Як підсилює зміст музика? Як виконання доповнює сприйняття пісні? Що спільного в цих творчих особистостей: поета, музиканта, виконавця?

Така аналітико-синтетична робота над змістом і формою тексту сприяє інтеграції сприймання і розуміння літературних творів і музики.

Ефективність інтегрування аудиторної та позааудиторної діяльності доведена практикою: авторка статті має досвід організації та проведення літературознавчих турнірів, брейн-рингів, конкурсів, вікторин (у тому числі, й одночасно в онлайн та офлайн режимі), які $€$ ефективним доповненням до лекційних, практичних занять, самостійної роботи студентів з історії української літератури. Наприклад, брейн-ринги «Квітка-Основ'яненко «батько української прози», «Великий артист зору Іван Нечуй-Левицький», «Пантелеймон Куліш: егоїст і егоцентрик, людина складного, багатого, контроверсійного життя», «Невільник честі» на поєдинку з епохою: життя і творчість Івана Багряного», які відбувалися в Міжнародному економіко-гуманітарному університеті імені академіка Степана Дем'янчука, є прикладом інтеграції навчальної, організаційної, виховної форм діяльності, адже «будь-який заклад освіти - це система полікультурного простору, який оперує мережею смислів освітньої, виховної, цінніснокультурної, моральної, поведінкової, соціальної спрямованості» (Полянкіна С., 2013, с.77)

В організації та проведенні заходів брали участь студенти четвертого курсу спеціальності «Українська мова та література», «Мова та література (англійська)», учасниками були команди першого, другого, третього курсів (ті, хто не був учасником, допомагали команді в підготовці і брали участь як групи підтримки під час проведення брейнрингу. Результатом проведення для всіх учасників стали значно глибші і різнобічніші знання з теми «Іван Франко. Життя і творчість» у взаємозв'язках з мистецтвом, перекладознавством, компаративістикою. Окрім формування предметних компетентностей, власне організатори та учасники вчилися працювати в команді, формували навички роботи з IKT та з іншими технологіями (проектною, критичного мислення), тобто оволодівали загальними та фаховими компетентностями. Окрім того, це й ціннісно-культурний, моральний, поведінковий, соціальний вплив на особистість студента.

Отже, у процесі інтеграційного вивчення дисципліни «Історія української літератури» у студентів формуються інтегративні знання, уміння та навички, які трансформуються в предметні (у курсі «Історії української літератури») та загальні компетентності, які зазначено в освітньо-професійній програмі: «Здатність вчитися і оволодівати сучасними 
знаннями», «Здатність зберігати та примножувати моральні, культурні, наукові цінності і досягнення суспільства на основі розуміння історії та закономірностей розвитку предметної області, її місця у загальній системі знань про природу і суспільство та у розвитку суспільства, техніки і технологій» (Освітньо-професійна програма, 2018).

У процесі такого навчання формується інтеграційно-літературознавча компетентність, що виявляється через мотиваційно-ціннісний, когнітивно-рефлексивний, креативно-діяльнісний складники, вона є вагомим складником професійної підготовки майбутніх учителів української мови та літератури.

\section{ВИСНОВКИ ТА ПЕРСПЕКТИВИ ПОДАЛЬШИХ ДОСЛІДЖЕНЬ}

Авторська методика інтегрованого вивчення історико-літературних монографічних тем засвідчила позитивні результати. Змістова та діяльнісна інтеграція допомагає всебічно розкрити запропонований навчальний матеріал, формувати загальні, предметні й фахові компетентності.

3 огляду на позитивні результати інтеграційного вивчення монографічних історико-літературних тем, необхідна апробація означеної методики в закладах вищої освіти, які готують майбутніх учителів української мови та літератури. Перспективними є наукові пошуки щодо інтеграційного вивчення «Історії української літератури» та «Історії зарубіжної літератури» на засадах змістової та діяльнісної інтеграції.

\section{СПИСОК ВИКОРИСТАНИХ ДЖЕРЕЛ}

Базиль Л. О. Формування літературознавчої компетентності майбутніх словесників шляхом інтеграції історико-літературних курсів. URL: http://gisap.eu/ru/node/717 (дата звернення: 27.11.2020).

Навчальний план підготовки здобувачів вищої освіти. Галузь знань: Освіта/Педагогіка Спеціальність 014 Середня освіта (Українська мова та література). Освітній рівень: Бакалавр. 2018. URL: https://www.megu.edu.ua/uk/istoriko-filologichnij/kafedra-ukrainskoimovi-ta-literaturi/ (дата звернення: 27.11.2020).

Нічишина В. В. (2014) Про науково-теоретичні засади підвищення ефективності професійної підготовки майбутніх учителів на основі інтегративного підходу. Наукові записки. Сер. Пед. науки. Кіровоград, №134. С.178 - 182.

Овдійчук Л. М. Іван Франко як особистість. Мультимедійна презентація. URL: https://drive.google.com/file/d/1c7Dqgign1m1ANQTpg2l1 R8BCGTm9Ew6O/view?usp=sharing (дата звернення: 27.11.2020).

Овдійчук Л. М. (2020) Інтеграційне вивчення історико-літературних монографічних тем у процесі підготовки майбутніх учителів української мови та літератури. Теоретична і дидактична філологія: збірник наукових праць. Серія «Філологія». Переяслав: Домбровська Я. М. Випуск 33. С. 66-78.

Освітня професійна програма 014 Середня освіта (Українська мова та література). 2018. URL: http://www.megu.edu.ua/wp-content/ uploads/2020/04/OPP-2016-2018-uml.pdf (дата звернення: 27.11.2020).

Полянкина, С. Ю. (2013) Понятие интеграции в категориальном аппарате философии образования. Интеграция образования. №2. C.76-82.

\section{REFERENCES}

Bazyl, L. O. (2020) Formuvannia literaturoznavchoi kompetentnosti maibutnikh slovesnykiv shliakhom intehratsii istoryko-literaturnykh kursiv [Formation of literary competence of future linguists through integration of historical and literary courses]. URL: http://gisap.eu/ru/node/717 (data zvernennia: 14.10.2020).

Navchalnyi plan pidhotovky zdobuvachiv vyshchoi osvity. Haluz znan: Osvita/Pedahohika Spetsialnist 014 Serednia osvita (Ukrainska mova ta literatura). Osvitnii riven: Bakalavr (2018) [Curriculum for higher education. Field of knowledge: Education / Pedagogy Specialty 014 Secondary education (Ukrainian language and literature). Educational level: Bachelor. 2018]. URL: https://www.megu.edu.ua/uk/istorikofilologichnij/kafedra-ukrainskoi-movi-ta-literaturi/ (data zvernennia: 27.11.2020).

Nichyshyna, V. V. (2014) Pro naukovo-teoretychni zasady pidvyshchennia efektyvnosti profesiinoi pidhotovky maibutnikh uchyteliv na osnovi intehratyvnoho pidkhodu [On scientific and theoretical principles of improving the effectiveness of professional training of future teachers on the basis of an integrative approach]. Naukovi zapysky. Ser. Ped. nauky. Kirovohrad, 134, $178-182$.

Ovdiichuk, L. Ivan Franko yak osobystist. Multymediina prezentatsiia [Ivan Franko as a person. Multimedia presentation]. URL: https://drive.google. com/file/d/1c7Dqgign1m1ANQTpg2l1R8BCGTm9Ew6O/view?usp=sharing (data zvernennia: 14.10.2020).

Ovdijchuk, L. M. (2020) Integhracijne vyvchennja istoryko-literaturnykh monoghrafichnykh tem u procesi pidghotovky majbutnikh uchyteliv ukrajinsjkoji movy ta literatury [Integrative study of historical and literary monographic topics in the process of training future teachers of Ukrainian language and literature. Theoretical and didactic philology: a collection of scientific papers]. Teoretychna i dydaktychna filologhija: zbirnyk naukovykh pracj. Serija «Filologhija», 33, 66-78.

Osvitnia profesiina prohrama 014 Serednia osvita (Ukrainska mova ta literatura). 2018 [Educational professional program 014 Secondary education (Ukrainian language and literature)]. URL: http://www.megu.edu.ua/wp-content/uploads/2020/04/OPP-2016-2018-uml.pdf (data zvernennia: 30.09.2020)

Poljankina, S. Ju. (2013) Ponjatie integracii v kategorial'nom apparate filosofii obrazovanija [The concept of integration in the categorical apparatus of the philosophy of education]. Integracija obrazovanija, 2, 76-82. 